\title{
Agentic Subjects and Objects of Political Propaganda: Swedish Media Representations of Children in the Mobilization For Supporting Finland During World War II
}

Johanna Sköld and Ingrid Söderlind

The self-archived postprint version of this journal article is available at Linköping University Institutional Repository (DiVA):

http://urn.kb.se/resolve?urn=urn:nbn:se:liu:diva-144797

N.B.: When citing this work, cite the original publication.

Sköld, J., Söderlind, I., (2018), Agentic Subjects and Objects of Political Propaganda: Swedish Media Representations of Children in the Mobilization For Supporting Finland During World War II, Journal of the History of Childhood and Youth, 11(1), 27-46. https://doi.org/10.1353/hcy.2018.0002

Original publication available at:

https://doi.org/10.1353/hcy.2018.0002

Copyright: Johns Hopkins University Press

http://www.press.jhu.edu/journals/ 


\title{
Agentic subjects and objects of political propaganda. Swedish media representations of children in the mobilization for supporting Finland during World War II
}

Johanna Sköld and Ingrid Söderlind

\begin{abstract}
Children are often portrayed as defenseless victims of war. However, during war periods, issues concerning children's agency are also brought to the fore. Based on media materials describing one country in war (Finland) and relief efforts from a neighbor country (Sweden) this article identifies both Finnish and Swedish children as committed to Finland's cause in different ways. Discussing the issue of authenticity when it comes to children's commitments, the article shows that children emerge both as agentic subjects and as objects of political propaganda. It argues that children's commitment as represented in the Swedish media could function as propaganda pressuring adults to take action.
\end{abstract}

\section{Author information}

Johanna Sköld is Professor of Child Studies at the Department of Thematic Studies, Linköping University (Sweden). Her research concern the history of foster care, apology politics aimed at historically institutionally abused children internationally and child evacuations during WWII. She is the co-editor (with Shurlee Swain) of Apologies and the Legacy of Abuse of Children in 'Care' (Palgrave Macmillan, 2015) and co-editor (with Kaisa Vehkalahti) of a special issue on methodological and ethical issues in the history of education and childhood in History of Education, vol 45:4 (2016).

Ingrid Söderlind is former Senior Lecturer at the Department of Social and Welfare Studies, and Docent (Associate Professor) in Child Studies at the Thematic Department, at Linköping University (Sweden). Her thesis concerned orphanages for girls in Stockholm 1870-1920 (1999) and thereafter she has been involved in research projects concerning foster care, children's citizenship, childhood and work, Nordic child welfare politics and child evacuations during WWII. She has mostly published in Swedish. In English she is the author of Orphanges for Girls in Stockholm 1870-1920. A Case Study in European Social History (2015), and co-editor of the anthology Children's Work in Everyday Life (2007). 


\section{Agentic subjects and objects of political propaganda. Swedish media representations of children in the mobilization for supporting Finland during World War II}

Children are often portrayed as defenseless victims of war. This notion has had several applications. For example, children have been important objects of wartime propaganda, as the innocence and vulnerability attributed to them can be used to mobilize defense as well as sympathy and, consequently, relief efforts. However, during war and periods of crisis, issues concerning children's agency and participation are also brought to the fore and ideals of children and childhood can be stretched and negotiated. ${ }^{1}$ This may concern everyday life as well as political struggle, and even actual fighting on the battlefield. Using media material from World War II, the present article seeks to demonstrate that, within the media, the passive role of the innocent victim has been supplemented with representations of the actively committed child. The aim of the article is to explore how media representations of agentic children were used for wartime mobilization, and thereby to discuss how children's agency can be understood in this specific historical context.

The point of departure for the study is the World War II mobilization in Sweden in support of Finland, which (unlike neutral Sweden) was involved in several wars during the period 1939-1945. Because of its neutrality, the Swedish government did not support its neighbor Finland with armed military forces, and it also had to balance other relief efforts so as not to upset Finland's enemies, first the Soviet Union that attacked Finland in 1939 and later on Great Britain and its Allies, when Finland during the so-called Continuation War 1941-1944 was allied to Nazi-Germany. These circumstances affected how some associations and political parties in Sweden acted, but on the whole there was a strong commitment to Finland and public authorities, municipalities, companies, trade unions, different kinds of 
associations (within churches, sports, military, women, scouts) as well as individuals were involved in various ways in the efforts to support Finland, and this support took numerous forms: armed volunteer corps, state loans, fundraising, clothing collections, medical care and treatment for sick children and adults at Swedish hospitals, and fundraising for the purchase of ambulances, interceptor aircrafts and so forth. Additionally, the evacuation of approximately 70,000 Finnish children to Sweden was part of the relief efforts, making it one of the largest inter-country child evacuation schemes in the Western world to take place during the twentieth century. The children mainly resided with Swedish foster families, but institutions for children were also established. $^{2}$

Based on Swedish media material, the present article explores how wartime commitment among children was described, and the roles in which children appeared in these representations. The media, such as the daily press, radio broadcasts and movies, constitute an arena of public life, both reflecting and influencing people's thoughts and acts. They form an important arena for advocacy, which actually was used during World War II by NGOs with the aim of mobilizing Swedes’ support for Finland, especially with regard to promoting the evacuation scheme. In effect, the relief efforts in Sweden in support of Finland received great attention in the Swedish media, as did Finnish efforts to defend the country and cope during the war years. The way children and their commitment were portrayed may be significant to both politics and everyday life, as it could influence the support given to Finland, but also to children's societal status in general. ${ }^{3}$ Using media materials thereby creates opportunities to explore: a) what kind of activities on the part of children for defending and supporting Finland were emphasized in the Swedish media and b) how children committed to the activities were described. Such an investigation can contribute to a discussion of the role of children in politics and of what role media representations of children and their activities might have played in mobilizing the Swedish public. 


\section{Children’s voice and agency}

At the heart of our discussion lies the conflict between children as subjects and agents in their own right, on the one hand, and children as objects of political measures, on the other. This conflict can be traced back to the birth of the new sociology of childhood, when children's voice and agency became the core of a research paradigm aiming to recognize children as social actors who are co-constructers of the world they live in. For historians, this paradigm has been especially challenging, as time transforms children into adults and historical sources produced by children themselves are only occasionally preserved. Lately, however, the “agency ideal” within childhood studies has been challenged. It has been argued that the concept of children's agency has been poorly defined and that it assumes, in an unreflected manner, certain competences; that it marks a dualism between children and adults; that the search for children's agency prevents the researcher from acknowledging the agentic expressions of the silent child, or the conformist child acting in line with adults' expectations; that what children themselves say too readily has been seen as an authentic representation of their voices, ignoring how the various positions of class, gender, age, sexuality, ability and ethnicity influence children's (as well as any adult’s) points of view. ${ }^{4}$

In accordance with these critical remarks from the research on contemporary children and childhoods, some historians have developed methodological approaches that enable them to "see” and "hear" children who are hidden or mute in the historical material. Kjersti Ericsson urges historians to consider a child's silence as an act of agency. A close reading of sources, with attention to details, can reveal hints as to children’s agency. Mona Gleason encourages historians to engage with "emphatic interference” by using their scholarly 
informed imagination and knowledge to read between the lines of primary sources where no apparent traces of children's agentic expressions are to be found. ${ }^{5}$

However, sometimes children do speak and act within historical sources. Just as outlined in the critique of the agency ideal, it would be naïve to interpret such accounts as authentic representations of children's perspectives. However, it is just as problematic to not consider what the sources might reveal about children's political and social agency. ${ }^{6}$ In the present study, which uses media as it primary source, we will emphasize three source critical aspects that might affect the interpretation of what children's perspectives are.

First, it must be acknowledged that media has the power to determine who has the right to talk, and to construct representations of those who talk, which in turn are intended to address specific audiences. ${ }^{7}$ The power imbalance can be even more obvious between an adult journalist or radio/TV host and an interviewed or cited child, which makes it important to look for how children are represented and how their agentic expressions can underpin or challenge the storyline.

In the present article, we study Swedish newspapers and a particular radio program: Children's Mailbox. The newspapers are Dagens Nyheter $(D N)$ - the leading newspaper in Sweden - and Hallandsposten (HP), a local newspaper in the province of Halland, located on the Swedish west coast, where many Finnish war children resided. The newspapers' political stance, as reflected on the editorial pages, was liberal. The newspapers are studied for the period of the Winter War (November 30, 1939-March 1940), and two periods (January-April 1942 and 1944) when many Finnish children were sent to Sweden during the Continuation War (June 25, 1941-September 19, 1944).

In total, about 670 newspaper issues have been scanned for news about Finnish children. A quite recently completed digitalization of newspapers facilitates quick searches by 
typing keywords into a database, but newspapers were only accessible through microfiche copies when we began our project. However, one advantage microfiche has over digitalized material is that the search is not limited to predefined keywords, which facilitates broader coverage; another advantage is that that one gets an overview of the issue and may see how different news items are related to each other. In fact, there is always a kind of competition between how news items are positioned in the newspaper, which may say something about how they are valued.

Altogether, Finnish children were mentioned in 135 issues of DN (of approximately 360 issues) and 100 issues in HP (of approximately 310 issues). Based on this vast material of 235 newspaper issues, we have identified slightly more than 30 texts/photos that explicitly address different kinds of commitments made by children. We will analyze four more in detail, and others will be referred to more briefly. The number of texts addressing commitments made by children are few by comparison, however the existence of them is a source to a more general discussion on how to critically elaborate on children's agency in history.

The two newspapers engaged in regular reporting about Finnish children; however, over time the news value seems to have diminished. During the examined periods, news items about Finnish children were published at most in half of the issues (DN 1942), and at least in a quarter of the issues (HP 1944). Some issues contained more than one reference to Finnish children. News items are found in different sections of the newspapers: on the front pages, on news sites, sometimes among local news and even on the sports pages. There is also variation in the size of the texts. However, shorter news items reporting the number of Finnish children arriving to Sweden, how they were welcomed and where they should be placed in Sweden are common, as are news items about events organized for them. Still, a number of longer articles on Finnish children were also published. Another essential part of the news 
material is photos with captions, which is typical as articles dealing with children were more likely to be illustrated with photos than were other topics covered by Swedish newspapers. ${ }^{8}$ Photos of children make the captions particularly interesting, as they guide the reader in interpreting the situation the children are in, which may say something about how children's agency is depicted from a journalist's point of view.

The daily press is an important part of the public sphere, but is primarily an arena for adult participation; in newspapers, adults write for other adults. The content reflects events and conditions adults wish to highlight, although they may be based on narratives concerning children's behavior and activities. ${ }^{9}$ It is evident from previous research that children's voices or visual representations of children imply certain notions of authenticity in wartime media material. In his study of publications about the Algerian War of Independence (1954-1962), Alexis Artraud de La Ferrière concludes that children’s voices functioned as a rhetorical force for propaganda, because their testimonies were regarded as authentic, and “thus were not interpreted as propaganda." On the other hand, de La Ferrière advises against a view in which children's testimonies are assumed to be politicized by adults, as if they themselves were never actively responding or willing to engage in political struggles. ${ }^{10}$ In the newspapers we have studied, some articles give the impression of representing children’s opinions either through direct quotes, referential style, adults' citations of children's stories or by formulations indicating that the journalist has approached children with questions. ${ }^{11}$ However, the fact that adult journalists construct children's voices and reflect their adult understanding of what the children have said does not rule out that newspapers could be a source of children's testimonies or enactment, if we, like Gleason and de La Ferrière did, carefully problematize the agency ideal's assumed dualistic relationship between children's and adults’ political agency and use scholarly knowledge about contexts to read between the lines. This becomes particularly apparent in the radio show Children's Mailbox, where 
children's narratives on relief work were to an even greater extent accentuated as authentic, however still directed by adults. The show's format was designed around children's participation, either with the popular radio host Sven Jerring - also referred to as "Uncle Sven” - reading letters children had sent him or through children's performances in the studio (singing, playing instruments, reading poetry). ${ }^{12}$ Children's Mailbox was a very popular program, and the initiative to write to Uncle Sven probably came mostly from the children themselves. However, adults made the selection of performances and letters. Unfortunately, neither the original letters to Uncle Sven nor the Children's Mailbox broadcasts during the war have been found, despite persistent searches in the archives. ${ }^{13}$ Instead we rely on a manuscript by journalist Gerda Marcus, in which children's letters are quoted, describing the great fundraising campaign engaging Swedish children in support of Finnish children, coordinated by the Swedish Save the Children's Fund and Sven Jerring in December 1939. ${ }^{14}$

A second aspect of source criticism is that we need to take a closer look at which children are represented, and from which positions they speak and act in the media material. Unlike studies of how children were mobilized for national defense by schools, the media material captures agentic expressions of even younger children. ${ }^{15}$ In addition to age, class, and gender, family situation and national residence are important in our study, because media representations of children from one belligerent and one neutral country during war may reflect very different experiences and ideas concerning childhood. As this study uses Swedish media, the material reflects events and actions that in a Swedish context were considered interesting to pay attention to, and how they were valued. Different results might be achieved if the Finnish media had been studied.

Third, studying media during any war constitutes a special circumstance: it calls for attention to censorship and propaganda. Despite its neutral position, the Swedish government introduced several regulative measures on the press during World War II, but 
these restrictions were mainly aimed at critical writings about Nazi Germany. The national radio broadcast company in turn was regulated to foster national unity and to downplay political debates and foreign policy matters. Hence entertainment, government information along with fundraising campaigns in support of Finland and Norway were common features of the Swedish radio broadcasts, which in turn means that Children's Mailbox was well suited to the tranquilizing ambitions of public service. In the Finnish media, criticism of the child evacuations to Sweden was censured from 1942, which can partly explain why problematic aspects of the evacuation scheme were only occasionally addressed in the Swedish media. ${ }^{16}$ In addition, the major NGOs in Sweden that were engaged in, and organized, the evacuation of the Finnish children had their own active press offices distributing propaganda on the success of the evacuation scheme. They supplied Swedish newspapers with news items and entire articles on Finnish children in Finland and Sweden. Photographs were also distributed by these press offices. ${ }^{17}$ This means that notions of children emphasized in the media, as either innocent victims of war or social and political agents, can in some cases be assumed to be under the direct influence of these NGOs’ ambitions to strengthen support for relief actions for Finland. While the studied radio show was part of the Swedish Save the Children's Fund's fund raising campaign, none of the newspaper articles considered for an in-depth analysis in the present study can be proven to have been distributed by the NGOs’ press offices, but naturally it is difficult to discriminate between NGO propaganda and independent journalism in this respect. However, the fact that articles could have been influenced by the NGOs’ press offices, and that the radio show clearly was a part of a NGO campaign, makes it relevant to investigate what kind of activities for defending and supporting Finland were emphasized and how children committed to these activities were described.

The NGOs operated a deliberative media policy, and they were aware of the influence the media had on public support for their relief efforts. This awareness of the 
media’s impact as well as of how children have been used in political rhetoric has been addressed in previous research. In her study of political posters, Dubinsky described pictures of children as visual tools for encouraging adult political enactment: "children appear so that adults can act”. ${ }^{18}$ A similar conclusion is drawn by deGraffenried in her study of children and childhood in the Soviet Union during The Great Patriotic War (1941-1945). According to her, visual representations of children as victims of war were used to mobilize adult support for the national war effort. But propaganda has not only been aimed at adults, children have also been a target audience. deGraffenried shows, using examples from children's films, literature and magazines as well as political organizations for children, that propaganda aimed at children played an important role in the Soviet Union during the war and that children who were making an effort for the country were emphasized and praised in particular. ${ }^{19}$ In a similar vein, Ross F. Collins, in his research on US magazines for children and material directed at teachers and Scout leaders during World War I and World War II, identified how authorities used propaganda in an attempt to influence children's thoughts and actions in order to support the country. Children were expected to participate in several war-related activities, and even though these were adult-initiated activities, Collins argues that children were active agents in this work. They were considered to be able to influence their parents and were therefore important to reach for government propaganda purposes. In this context, Collins emphasizes the importance of the child and youth organizations established in many countries during the early twentieth century, some of them explicitly connected to political organizations. ${ }^{20}$ Neutral humanitarian youth organizations also experienced elements of politicization during the war. Sarah Glassford describes how the Junior Red Cross in Canada (JRC) shifted its focus from peace-building internationalism to patriotic voluntary service during World War II. At its peak, twenty-five percent of Canadians aged five to nineteen were members of this organization and made substantial contributions to the wartime humanitarian 
aid effort. Glassford argues that even if JRC participation was imposed on children by adults (the JRC programs were run by teachers), this "does not mean that children could not also be willing - even enthusiastic - participants.”21

Finnish children and war in Swedish newspapers

Previous research on children and war in the media has shown that there is often a preference for depicting children as being in need of protection. ${ }^{22}$ Our study of two Swedish newspapers confirms this preference for describing children as innocent victims of war. Reports from Finland related that children lacked food and proper supervision, and were exposed to bombs. ${ }^{23}$ It is a vulnerable childhood that appears in the news, reinforced by general reports from a Finland at war and of the country's strains and difficulties. However, the fact that children are presented as victims does not imply that they were presented as passive. A close reading of the newspapers shows that children also were presented as defending and supporting Finland in different contexts. Consequently, both the rhetorical figure of the child victim and the figure of the agentic competent child emerge in Swedish newspapers, and even more importantly, both appear as children deserving of support. In this article we focus on the figure of the agentic competent child.

In the research on children and childhood, work appears as a context that challenges notions of childhood during wartime. At the outbreak of World War II, schooling had become an important part of children’s lives in many countries, but during the war, school attendance decreased when young people were needed on the labor market. According to Marten, many American children stopped attending school in order to work and hundreds of schools closed. The same occurred in other countries. ${ }^{24}$ In Finland a Work Responsibility Act (työvelvollisuuslaki) stipulated that everyone aged fifteen to sixty-four years was “obliged to 
work in the war industry, agriculture and forestry or in other fields crucial for national defense”. ${ }^{25}$ Still, younger children were also mobilized to work for the national defense. Schools were closed in Finland too, with a reduction in lectures and many children participating in organized labor activities. In mid-February $1940 \mathrm{DN}$ published an article with the headline ”50,000 Finnish children will serve as farm help”. The article was written by the newspaper's correspondent in Finland and states that children and youth would be engaged to grow vegetables in the coming spring. ${ }^{26}$ The initiative was reported to come from the organization Lantbruksklubbförbundet, which was close to the leading military field marshal Mannerheim. The idea was to put 12- to 17-year-old to work. The text mentions 12 years as the lower age limit, but according to the article younger children had asked to join the project. An adult being interviewed is said to be quoting what children have expressed: "We don't want to sit here and be 'pitiful kids': we want to help.” The same adult conveyed the voices of children and also promised to grant their wish -“they will be asked to help.” No children are quoted in the text, however there are references to what children say and what they want. ”Never believe that it is only an adult's idea to put children to work cultivating patriotic potatoes” the correspondent wrote, thus describing the project as something the children themselves wanted to carry out: "Young children demand (our Italics) their right to help during the country's most difficult years." Formulations such as "demand" and "their right" presented the children as agentic and committed, and the correspondent argued that children's awareness of the nation's vulnerability was a basis for their effort.

The news value of this article was not ascribed to the fact that children and youth were working, as this was a common feature of childhood in rural areas, where many of the Finnish population resided. ${ }^{27}$ Rather, it emphasized that children were making an effort for the nation, which was something other than helping out at home. The article is about an agricultural project, though words connected to war are used: “[...] Finland is strengthening 
its home front. No one is excluded, no one is allowed to be idle. Now it is the 9-year-old children's turn to contribute," the article stated. The correspondent mentions “the 9-year-old's own army,” and according to the correspondent, this army would set up with shovels and picks and tough small Finnish pinches. With the expression "tough small Finnish pinches” the article displays that views on ethnicity also influenced how agency was expressed. The description is in line with how adult Finnish refugees were talked about in the public debate: tough and durable. ${ }^{28}$ The article focused on quite young children, but did not present them as victims. It conveyed a view of 9-years-olds as active participants in the defense of their country.

The fact that working children were needed in Finland was also highlighted in an interview with Elsa Bruun, who in Finland was in charge of the evacuation of Finnish children to Sweden. According to how she was quoted, the reason for sending quite young children to Sweden was that they could not help with anything, and she also stressed that children old enough to make an effort should stay in Finland. Hence, Finnish authorities here represented by Bruun - were presented as using incapacity to do labor as a justification for sending quite young children to Sweden, many of them only 2 to 3 years old. This argument was compatible with the fact that, in Sweden, the demand for younger children was far greater than that for adolescents among the many families that rallied to invite Finnish children into their homes. ${ }^{29}$

Another core phenomenon described as contributing to the nation was how children collected metal for the Army, something that engaged children in other countries in as well. ${ }^{30}$ One photo with caption in the Swedish newspapers addresses Finnish children performing this kind of work. ${ }^{31}$ The photo shows girls with metal that they have collected. There is no information about the girls - no names, no comments from them - but they look happy. Perhaps the photographer had asked them to smile. A smile in this context could 
convey an image of pride after having made an effort considered important to the nation. According to the caption young people were taking the lead in collecting metal, whether they had initiated it was not clear. In addition, Finnish children, just like children elsewhere, collected waste paper and cones. ${ }^{32}$ These activities were not mentioned in the Swedish newspapers, however. Perhaps direct contributions to the Army were considered more important to tell Swedish readers.

A photo of an 11-year-old boy with a rifle, published in HP January 1944, is even more directly related to the Army. According to the caption text, the boy had run away from home to join the Army, but was considered too young and sent home. Doing like this Finnish boy did is known from other countries as well, ${ }^{33}$ and additional examples from Finland are also found in our data. ${ }^{34}$ Finland had large child and youth organizations that were closely linked to the Army: one for boys, The Soldier Boys, and one for girls, The Lotta Girls. In the caption, nothing is said about the boy being a member of The Soldier Boys and whether or why he might have been inspired to join the Army, but he does pose with a rifle, probably borrowed from a soldier. Perhaps this also concerns the boots, which seem very big in relation to the boy. In Finland, the age limit for admission to the Army was sixteen. The age limit expresses both a notion of risks as well as a notion of lack of combat competence among young boys. The boy in the photo was much younger, eleven years old according to the caption, yet he is posing with a rifle as if he belonged to the Army. The photo and caption may be interpreted as a Swedish local newspaper's desire to show that children, or at least young boys, longed to make a military effort in Finland, which in turn was considered to convey a message to the Swedish audience. The idea of allowing children of this age to handle weapons had been debated in Sweden a few years earlier, when a state commission proposed compulsory military training for school children, where rifle shooting was seen as appropriate training for boys aged 12. The commission was established in part as a response 
to an appeal made by pupils who wanted military training, thus indicating that (some) Swedish children wished to make a military effort. Eventually, the commission's proposal was turned down by the parliament, and compulsory military training was introduced only at grammar schools for youth aged 16-20. ${ }^{35}$ However, the idea of the militarily competent child had been reflected both by experts and by pupils in several Swedish schools, hence the Finnish boy soldier in the newspaper could be interpreted as a reminder of the contribution children could make to the nation, in Finland as well as in Sweden.

The above-mentioned children who engaged in organized agricultural work and military activities were portrayed as competent children taking on adult responsibilities during wartime. This is also expressed in texts mentioning sibling relations among evacuated children as well as children residing in war-torn Finland. Older siblings taking care of younger brothers and sisters is a recurring theme in this context. For instance, an 11-year-old girl is described as "a little mother" to her younger siblings. ${ }^{36}$ Even quite young children were portrayed in such positions. In the caption of a photo of two siblings who had come to Sweden, one of them - a boy of four years - is described as being responsible for his 2-yearold sister. ${ }^{37}$ The very fact that older siblings took care of their younger brothers and sisters was not remarkable; this was self-evident in many families even during peacetime. Yet it was highlighted in the press during war, which may be related to changing family conditions and separation from parents. Older siblings were thus expected to take on more responsibility than usual. In the newspapers, children's agentic expressions as carers are described as important to family members.

Entertainment and parties often played an important role in mobilizing support during wartime, ${ }^{38}$ and also constituted a context where Finnish children appear in the Swedish newspapers. The events are described as having a clear purpose - to arouse public support for Finland and to collect money. On several occasions, Finnish children's performances were 
integrated into programs featuring adult speakers and aimed at adult audiences. The Finnish children performed by reading poetry, singing and playing music for Swedish adults, and sometimes also for Swedish children. ${ }^{39}$ The events were organized by adults, and it can be assumed that Finnish children, just like the iconized children in the political posters Dubinsky studied, were considered to "move emotional and psychic mountains" 40 and hence to add something other (courage, sympathy, hope) than mere entertainment. In the newspapers, performing Finnish children were attributed influence, and as a consequence were used for political propaganda purposes. However, this does not exclude the possibility that the children themselves were politically engaged in their performances.

The Sunshine Kids was a group of performing children whose aim was to rally support for Finland. The children in this singing group were not evacuated. They lived in Finland and travelled to Sweden with the particular objective of performing to increase support. The group consisted mostly of 9- or 10-year-old children, but one 4-year-old girl caught the particular attention of the press. ${ }^{41}$ The presentation of the Sunshine Kids in $D N$ in February 1940 conveys that they were performing a clear political message: "Four-year-old Rosa Li will sing a new song, 'Daddy is fighting against the Russians'.” According to the article, the show also included a reading of the drama of David and Goliath by FinnishSwedish author Zacharias Topelius. ${ }^{42}$ The depiction of David and Goliath was no coincidence; in Finland, combatting the Soviet Union during the Winter War was described as the fight between David and Goliath. ${ }^{43}$ Based on how the Sunshine Kids were described, the children could be characterized as political activists. However, based on their ages, adults presumably played an important role in organizing the group’s performances and travels, although this was not mentioned in the newspapers.

Swedish children committed to the Finnish cause 
Swedish children were also engaged in supporting Finland. Their support was mainly through schooling and the various youth organizations that had thrived since the beginning of the twentieth century. At the outbreak of World War II, many children and young people, in Sweden and elsewhere, were committed to organizations such as the Scouts or those linked to political parties or stakeholders, such as the Farmers' Youth League (JUF). As for Swedish children who were engaged in the relief efforts for Finland, three groups are particularly mentioned in the press: Sunday school children, Scouts and school children. They represent huge numbers, which were partially overlapping. The Scouts and the religious Sunday schools were both associated with the bourgeoisie, whereas youth organizations associated with the labor movement were not as prevalent in the material we have examined. ${ }^{44}$

December 8, 1939 - only a week after the outbreak of the Winter War - a news item reported that the Swedish council of Sunday schools asked Sunday school children to help their Finnish comrades by collecting clothes. This was described as an aid effort from children to children. ${ }^{45}$ In a similar vein, the Scouts were quickly drawn into the relief work supporting Finland, and Scouts seem to have played an important role in many countries during the war. ${ }^{46}$ In Sweden, the Scouts were one of the self-evident organizations to call when local relief committees were to be established. For example, newspapers reported on Scouts assisting with collecting clothes and creating a hurdle at the railway station in Stockholm to ensure that Finnish evacuated children would not be lost upon leaving the train. ${ }^{47}$ Scouts were also considered suitable for taking care of evacuees of their own age - the scouting age. ${ }^{48}$ The Swedish Scouts were not engaged exclusively in the relief work supporting Finland, but also in the Swedish civil defense.

Swedish school children adhered to several calls in support of Finland during different stages of the war. At the outbreak of the Winter War, popular radio show host Uncle 
Sven [Jerring] urged Swedish children to raise money for the Finnish children on his show Children's Mailbox. As this fundraising appeal was made around Christmas time, there were plenty of holidays to organize events around. As the upcoming Lucia feast was usually celebrated through school parties, Uncle Sven suggested that the profits be donated to support the Finnish children. In honor of the day, Children's Mailbox would broadcast an extra-long program that pupils could listen to during the parties. The money collected was donated to the Save the Children's Fund. This fundraising appeal had great success; in only a couple of weeks, 447,000 SEK had been collected (approximately twelve million crowns, or 1.3 million Euros in current currency). ${ }^{49}$ The money was largely a result of the children's efforts, but many adults also joined Uncle Sven’s fundraising. Companies and their staff donated money, as did "some simple working wives" and a principal who donated the gift he had received on his fiftieth birthday from the children at his school. It seems that the children's fundraising enthusiasm, as presented on the radio, also gave adults the incentive to act. ${ }^{50}$

On January 11, 1940, when the fundraising had been underway for a month, Margit Levinson, President of the Swedish Save the Children's Fund, gave a speech on the radio show to express her gratitude to the Swedish children. In the speech, she quoted some of the 500 letters children had written to Uncle Sven during the fundraising campaign. The speech as such is not preserved, but in a memorandum on the campaign written in 1941 by Gerda Marcus, journalist and member of the Save the Children's Fund, she claims to quote the Levinson speech, which in turn cites the children's letters. ${ }^{51}$ A source like this is problematic with in many ways, but it actualizes questions on whether historians can convey anything about children's agency from imperfect sources and whether dismissal of such sources contributes to our ignorance of children's political and social agency? We argue that, based on these quotes, we can gain insight into how children were committed to a campaign that, thanks to radio, reached far outside the cities to very remote areas in the countryside. 
Although the initiative came from adults like Uncle Sven, Margit Levinson or teachers, who had organized school parties or selected which narratives to highlight, there also appears to have been considerable creativity among the children themselves regarding how they could contribute.

Several children are said to have been telling of the work they had performed in support of the campaign. Åke and Kerstin, who lived in a region where many households had no telephone, had earned sixteen SEK by delivering telephone messages and milk. Two boys, aged eleven and eight, donated their earnings from repairing fishing nets and cleaning herring cans. Six-year-old Stig had sold shoelaces, while a girl named Ingrid donated her earnings from selling Christmas magazines. Both girls and boys had helped their mothers with household chores, and had donated the money they had received in payment.

Performances were a common source of fundraising among children, according to the speech of Margit Levinson. Four children skied down a mountain, collecting money from the audience (about eighteen SEK). Others put on plays, while Lars-Erik, six years old, had played his harmonica and earned four SEK. The Christmas festivities spurred all kinds of performances. Levinson mentioned so-called star boys and star girls, who walked around villages singing for money. Christmas season also meant that many children gave away their Christmas gifts or Christmas money. As described by journalist Gerda Marcus, Sven Jerring’s office was flooded with toys, dolls and clothes, donated by children. Savings were donated as well. By making explicit what the Swedish children had saved their money for, Levinson marked the sacrifices they had made:

“Lasse Dahlén, eight years old from Bengtsfors, has also made sacrifices for his beloved Finland. He had saved forty-seven crowns and thirty cents for a canoe, but has sent it all to Finland."52 
Still, if the Swedish children were described as making sacrifices for their Finnish peers, the campaign was characterized by play and ingenuity. As the program format encouraged them to send letters that could be read during the broadcast, many children attached poems or funny anecdotes, presumably to be rewarded if their creates were read on the program. However, Levinson cited unselfish altruism, quoting a letter from a boy who wrote "Mom says it's just as fun to give even if you're not mentioned on the radio, and I agree with her."53

During the Continuation War, Swedish school children were again invited to contribute to helping Finnish children. A call mentioned in $D N$ in February 1942 declared that pupils were to make “a personal sacrifice” by giving up their spending money. All school levels would be involved, from elementary to high school. Even colleges and seminars were included. ${ }^{54}$ In addition, the Relief Committee for the Children of Finland distributed special cards to the schools for collecting money. The cards were sent to all schools, a total of about 15,000 , with the teachers acting as intermediaries. ${ }^{55}$

\section{Conclusions}

The objective of the present article was to analyze how children committed to Finland's cause were represented in the Swedish media, and what role the media representations of children and their activities might have played in mobilizing the Swedish public. Our results demonstrate that the Swedish media which we have studied presented both Finnish and Swedish children as committed to the Finnish cause, and children emerged both as agentic subjects and as objects of political propaganda.

One central theme, which corresponds to how children have been addressed in propaganda elsewhere, is that the voices and agentic expressions of children are presented as 
authentic, and consequently, many acts are described by the media as having been initiated by children. Still, in several cases it is obvious that adults were involved in launching the relief efforts and war activities in which children participated. Therefore, it is difficult to disentangle the genuine commitment of the children from the adults' initiatives and political motives. However, as pointed out by de La Ferrière, “...children are not necessarily politicized against their will.” He argues that even if adults are active in producing children’s testimonies on war, we should not conclude that "children themselves have no political intent or awareness within this pipeline.”56

The children committed to Finland's cause who were portrayed and described by the Swedish media had quite diverse relations to, and experiences of, war. Yet this study demonstrates that both Finnish and Swedish children, as reported by the media, were involved in similar activities such as work or performances in support of Finland. However, there are also notable differences between the portrayal of Finnish children in Finland and that of Swedish and Finnish children residing in Sweden.

Finnish children in Finland, in addition to being represented as victims, were described as heroes making an effort for their nation. The concept of "heroes" in reference to children can be associated with nationalism, but also seems to connote taking on adult responsibilities. Children taking part in agricultural labor, minding siblings, gathering metal for the Army - or even trying to join the Army - replaced adults when none were at hand, or struggled alongside them. The very fact that children entered adult roles is emphasized in news articles from Finland, and when children’s ages are mentioned, they are often described as young in relation to their efforts: 9-year-olds building an agricultural army, an 11-year-old girl said to act as “a mother”, a boy aged four described as being responsible for his 2-yearold sister, a boy aged eleven ran away from home to join the Army. In this way, the situational context of war attributed attention to children's efforts in everyday life. Taking 
care of younger siblings and helping with agricultural work were experiences shared by many Finnish children. But when newspapers paid attention to such cores during the war, this attention made visible work that otherwise went without saying.

The Finnish children's position was in many ways represented as vulnerable, which in previous studies of propaganda has been demonstrated to be a way of gaining attention and support. ${ }^{57}$ However, vulnerability was mediated not only through starvation and hardship - it also appeared through the children’s adult responsibilities. In this respect, a country dependent on the efforts of its children appeared as worthy of support.

By contrast, the Swedish and Finnish children making efforts to support Finland in Sweden were portrayed as children, with no reference to adult responsibilities. Their efforts were characterized more by play and voluntary work, as described in the Swedish media. This is especially true of performance activities, with the children described as quite innovative and cheerful, reinforcing Western (peacetime) childhood ideals. One telling example of this is how the youngest member of the singing group the Sunshine Kids was photographed being lifted onto a table where she then stood and sang. Standing on a table reinforced her appearance as a child.

Performances such as those by the Sunshine Kids, and the performances and voluntary work described in the letters to Uncle Sven, highlighted children’s agentic expressions in support of Finland, and appear as part of the more general mobilization in Sweden. However, their agency also conveyed a message to adults. It was demonstrated that everyone - even children - can make an effort, and that this support could take many forms. We argue that the letters quoted in Children's Mailbox and the performances by children encouraged and challenged adults to engage in the relief work, as evidenced by the numbers of adults who donated money through Uncle Sven’s fundraising appeal in support of the Save the Children Fund. 
In the Swedish media studied here, children are described as committed and competent agents, but a critical analysis also conveys that the rhetorical force attached to images of children and children’s voices was used for political purposes. The very mobilization of children was important in many ways. In Finland, children could replace adults. In Sweden, children themselves contributed through monetary and relief efforts, but their commitment could also function as pressure on adults to take action. Children's commitment in both Finland and Sweden, as represented by the Swedish media, was intended to spur all of Swedish society to commit to the Finnish cause.

1. James Marten, “Children and war”, in The Routledge History of Childhood in the Western World, ed. Paula S. Fass, (London: Routledge, 2013), 142-157; Karen Dubinsky, “Children, Ideology, and Iconography: How Babies Rule the World”, Journal of the History of Childhood and Youth 5, no. 1 (2012): 7; Kevin Myers, “The Ambiguities of Aid and Agency: Representing Refugee Children in England, 1937-8”, Cultural and Social History 6, no.1 (2009): 30, 33; Julie K. deGraffenried, Sacrificing Childhood. Children and the Soviet State in the Great Patriotic War, (University Press of Kansas, 2014).

2. Johanna Sköld \& Ingrid Söderlind, "Finska barn i svenska hem: Om mobiliseringen av familjer att ta emot främmande barn under andra världskriget”, Scandia 82:1 (2016); Karin Zetterqvist Nelson, “War Children, Evacuations, and State Politics in Europe During WWII: A Local Case of Sick Finnish War Children in Sweden”, in Conflict, Violence and Peace: Geographies of Children and Young People, eds. C Harker et al. (Singapore: Springer, 2015), 1-21; Ann Nehlin, "Building Bridges of Trust: Child Transports from Finland to Sweden during the Second World War”, War \& Society 36, no. 2 (2017): 133-153; Pertti Kavén, Krigsbarnen: förväntningar och verklighet, (Hangö: Pertti Kavén 2011); Erik Carlquist, Solidaritet på prov: finlandshjälp under vinterkriget, (Stockholm: Allmänna förlaget 1971).

3. Cf. Ingrid Söderlind \& Kristina Engwall, Var kommer barnen in? Barn i politik, vetenskap och dagspress (Stockholm: Institutet för Framtidsstudier 2005), 98-99.

4. Allison James, “Giving Voice to Children’s Voices: Practices and Problems, Pitfalls and Potentials”, American Anthropologist 109, no. 2 (2007): 261-272; Spyros Spyrou, “The Limits of Children’s Voices: From Authenticity to Critical, Reflexive Representation”, Childhood 18, no. 2 (2011): 151-165; David Lancy, “Unmasking Children’s Agency”, AnthropoChildren 2 (2012): 1-20; Spyros Spyrou, “Researching Children’s 
Silences: Exploring the Fullness of Voice in Childhood Research”, Childhood 23, no. 1 (2016): 7-21; Gunilla

Halldén, “Barndomssociologi och möjligheten av ett psykosocialt perspektiv”, in Den moderna barndomen och barns vardagsliv, ed. Gunilla Halldén (Stockholm: Carlsson 2007), 25-40.

5. Kjersti Ericsson, “Children’s agency: The Struggles of the Powerless” in Apologies and the Legacy of Abuse of Children in 'Care’: International Perspectives, eds. Johanna Sköld \& Shurlee Swain (Basingstoke: Palgrave Macmillan, 2015), 51-52; Mona Gleason, “Avoiding the Agency Trap: Caveats for Historians of Children, Youth, and Education”, History of Education 45, no. 4 (2016): 446-459. Cf. how Karin Zetterqvist Nelson has scanned scarce brief notations in medical records on sick Finnish children treated at a Swedish hospital during World War II for signs of child agency. Zetterqvist Nelson, "War Children, Evacuations, and State Politics”, 1617. See also Carlo Ginzburg, Clues, Myth and the Historical Method (Baltimore: The John Hopkins University Press 1989).

6. Alexis Artraud de La Ferrière, "The Voice of the Innocent: Propaganda and Childhood Testimonies of War” in History of Education 43, no. 1 (2014):118-120; Célia Keren, “Spanish Refugee Children in France, 1939: An Insight into Their Experiences, Opinions and Culture”, Bulletin of Spanish Studies: Hispanic Studies and Researches on Spain, Portugal and Latin America 89, no. 7-8 (2012): 279-293.

7. Madeleine Hurd, Tom Olsson and Patrik Åker, "Introduction” in Storylines: Media, Power and Identity in Modern Europe, eds. Madeleine Hurd, Tom Olsson and Patrik Åker (Stockholm: Hjalmarson \& Högberg Bokförlag 2002), 10-11.

8. Karin Becker, “The Changing Picture of/on the Newspaper Page” in Picturing Politics: Visual and Textual Formations of Modernity in the Swedish Press, eds. Karin Becker, Jan Ekecrantz \& Tom Olsson (Stockholm: JM, 2000), 143-144. Photos of buildings where Finnish children were planned to be placed but with no children visible are not included in our study, nor are photos showing adults engaged in activities concerning Finnish children but where children are missing.

9. Söderlind \& Engwall, Var kommer barnen in?, 14-15.

10. de La Ferrière, “The Voice of the Innocent”, 117-120.

11. Cf. Söderlind \& Engwall, Var kommer barnen in?, 109.

12. Ingegerd Rydin, Barnens röster. Program för barn i Sveriges radio och television 1925-1999 (Stockholm: Stiftelsen Etermedierna i Sverige, 2000), 34-35.

13. Rydin, who has studied programs for children on Swedish radio and television, has found that children’s radio programs were only occasionally preserved during the interwar and war years. Rydin, Barnens röster, 21- 
22. Through a request to the Swedish Radio Broadcast company's document archives, we discovered that no letters to Uncle Sven were preserved.

14. The National Archive of Finland (NAF), E H:8.2, Gerda Marcus, Rädda Barnens, Radiotjänsts 'Farbror Svens' och de svenska skolbarnens insamling dec 1939-jan 1940 för finska krigsvärnlösa barn (hereafter RBRFS), November 3, 1941.

15. Esbjörn Larsson, ”Att fostras för landets försvar: Värntjänstutbildning för pojkar och flickor under andra världskriget”, Militärhistorisk tidskrift, no. 1 (2015): 89-134.

16. Klas Åmark, Att bo granne med ondskan: Sveriges förhållanden till nazismen, Nazityskland och förintelsen (Stockholm: Bonniers, 2011), 209-234; Kavén, Krigsbarnen, 66-71; Tekniska museet, ”Radion under andra världskriget” in tekniskamuseet.se. December 22 2009, viewed December 15 2016, http://www.tekniskamuseet.se/1/1106.html

17. Sköld \& Söderlind, "Finska barn i svenska hem”.

18. Dubinsky, “Children, Ideology, and Iconography”, 8.

19. deGraffenried, Sacrificing Childhood, 2, 91, 105, 118.

20. Ross F. Collins, Children, Children, War \& Propaganda, (New York: Peter Lang, 2011), xv, 43, 54, 147 and Chapter 5.

21. Sarah Glassford, "Practical Patriotism: How the Canadian Junior Red Cross and its Child Members Met the Challenge of the Second World War”, Journal of the History of Childhood and Youth 7, no. 2 (2014), 232.

22. Astri Andresen, et al., Barnen och välfärdspolitiken. Nordiska barndomar 1900-2000 (Stockholm: Dialogos, 2011) Chapter 7; Myers, “The Ambiguities of Aid and Agency”, 33; deGraffenried, Sacrificing Childhood; Pirkko Rönkkö, Finska krigsbarn i text och på pressbilder i Sverige och Finland (Tammerfors: Tammerfors universitet, 2007).

23. For instance, $D N$ January 13, 1940; January, 7 and 12 1942; HP February 12, 1940: February 12, 1942. 24. Marten, “Children and war”, 150; Mayall \& Morrow, You can help your country, 1; deGraffenried, Sacrificing Childhood; Marianne Junila, "Wars on the Home Front: Mobilization, Economy and Everyday Experiences,” in Finland in World War II, eds. Tiina Kinnunen and Ville Kivimäki (Leiden: Brill, 2012), 25. Marianne Junila, “Wars on the Home Front”, 208.

26. DN February 13, 1940. Children in other countries took part in cultivating projects as well. For England, see Mayall \& Morrow, You Can Help Your Country, 91, 101. For the Soviet Union, see deGraffenried, Sacrificing Childhood, 149. 
27. Saara Tuomaala, “Inte tid för skolan. Den finländska agrarbarndomens janusansikte under 1920- och 1930talen” in Jordbrukets barn. Barns och ungdomars fostran i agrara miljöer, ed. Mats Sjöberg (Stockholm: Nordiska museets förlag, 2004), 140-171.

28. Mikael Byström, En broder, gäst och parasit. Uppfattningar och föreställningar om utlänningar, flyktingar och flyktingpolitik i svensk offentlig debatt 1942-1947 (Stockholm: Stockholms universitet, 2006), 235.

29. HP April, 4, 1942; Sköld \& Söderlind, ”Finska barn i svenska hem”, 47.

30. For the US, see Collins, Children, War \& Propaganda, 55.For the Soviet Union, see de Graffebried, Sacrificing Childhood, 149.

31. HP March 17, 1942.

32. Junila, “Wars on the Home Front”, 210. See Mintz, Huck’s Raft, 258, for a similar list for the US. Collins argues that fundraising was regarded as particularly suitable for younger children. Collins, Children, War and Propaganda, 55.

33. Marten, "Children and war”, 150-151; Elizabeth A. Galway, “Competing Representations of Boy Soldiers in WWI Children’s Literature”, Peace Review: A Journal of Social Justice 24, no.3 (2012), 298-304; Tim Cook, “'He was Determined to Go’: Underage Soldiers in the Canadian Expeditionary Force”, Histoire sociale/Social history 41, no. 81 (May 2008): 41-74; Stéphane Audouin-Rouzeau, ”Quand les enfant font la guerre”, L’Histoire, no. 169 (1993); de Graffenried, Sacrificing Childhood, 31, 64.

34. DN October 13, 1941; Scouten: tidskrift för Sveriges scoutförbund no 3, March 1940, 66.

35. Larsson, ”Att fostra landets försvar", 96-98, 113.

36. HP January 19, 1940. Also HP December 22, 1939.

37. HP February 14, 1944. Also HP January 19, 1940.

38. Junila,’Wars on the Home Front”, 218.

39. For instance DN January 14 and 29 1940; HP February 16, 1940;

40. Dubinsky, “Children, Ideology, and Iconography”, 10.

41. DN January19 and 24, 1940; February 4 and 9, 1940; HP January 25, 1940: Husmodern 5 (1940), 25.

42. DN February 9, 1940.

43. Junila, "Wars on the Home Front”, 196.

44. On JUF (Farmers’ Youth League), see Kent Waltersson, “Med kunskap och redskap ska jorden odlas. Livet i Unga Odlare 1930-1960”, in Jordbrukets barn. Barns och ungdomars fostran i agrara miljöer, ed. Mats Sjöberg (Stockholm: Nordiska museets förlag, 2004), 172-195; on Scouts and Sunday schools, see Göran Sidebäck, 
Kampen om barnets själ: barn- och ungdomsorganisationer för fostran och normbildning 1850-1980

(Stockholm: Stockholm University 1992).

45. DN December 8, 1939.

46. For England, Mayall \& Morrow, You Can Help Your Country, 213. For the US, Collins, Children, War and Propaganda, Chapter 5.

47. DN March 3, 1940.

48. $D N$ December 12, 1939.

49. Sven Jerring, Sven Jerring, radioman: Farbror Sven berättar sina minnen (Stockholm: Natur och Kultur 1970), 97-99. The calculation tool for transforming historical prices into current currencies is available at http://www.historia.se/, see also Rodney Edvinsson \& Johan Söderberg. “A Consumer Price Index for Sweden 1290-2008”, Review of Income and Wealth 57, no. 2 (2011): 270-292.

50. NAF, E H:8.2, Gerda Marcus, RBRFS, November 3, 1941.

51. NAF, E H:8.2, Gerda Marcus, RBRFS, November 3, 1941.

52. NAF, E H:8.2, Gerda Marcus, RBRFS, November 3, 1941, 5.

53. NAF, E H:8.2, Gerda Marcus, RBRFS, November 3, 1941, 4.

54. DN February 7, 1942; HP March 13, 1942.

55. Swedish National Archive, Relief Committee for the Children of Finland, BI:1, Missive September 25, 1944.

56. de La Ferrière, “The Voice of the Innocent”, 119-120.

57. Dubinsky, “Children, Ideology and Iconography”, 7-8; Meyers, “The Ambiguities of Aid and Agency”, 33. 